

\section{Violence, Oppression, and Double Standards in Three Colombian Films}

This article compares three Colombian films that tell distinct stories of violence, personal and political oppression, and double standards. The films Confesión a Laura (Confessing to Laura, Jaime Osorio, 1991), La Primera Noche (The First Night, Luis Alberto Restrepo, 2003) and El Rey (The King, José Antonio Dorado, 2004) each highlight the characters' struggles in the Colombian socio-political landscape. Each film's content and themes do not merely offer representations of national culture, but also provide a way in which to discuss the political and social struggles of Colombia. The directors explore these stories of violence and socio-political struggle through the use of mis-en-scène, cinematography, sound, and editing.

El Bogotazo, a several day riot beginning a long period of violence in Colombia, occurred on April 9, 1948 when an assassin ended the life of liberal presidential candidate, Jorge Gaitán. Confesión a Laura takes place on the date of the assassination. The protagonist of the film, Santiago, lives with his wife Josefina across the street from a single woman named Laura. Despite the mayhem and audible shooting in the streets outside, Josefina has a host of preoccupations including the purchase of the best spices and confectionary items and sending Santiago on dangerous errands. Since it is Laura's birthday, Josefina has baked a cake and insists that Santiago take the risky walk across the street to deliver it. Josefina wants to be the first to send a gift to Laura; however, her desire to be first is not out of affection for Laura, but rather a competition to be the first with a nice gift. This unreasonable request sets the major theme for the film. Santiago experiences oppression from Josefina in his personal life. Osorio uses the milieu of Santiago's marriage to draw parallels between his personal and political oppression. Through the use sound, editing, and mis-en-scène elements such as setting, props, and behavior, Osorio explores the dual oppression of Santiago, ultimately liberating his character.

At the beginning of the pivotal fifth scene, the spectator sees the tension of Santiago's personal oppression. Although most of the film takes place in Laura's apartment, the camera captures Josefina in her own apartment via a medium shot. By this point, Santiago is trapped in Laura's apartment because the violence in the street has escalated. Josefina makes a telephone call to Laura's apartment, an action that she intrusively repeats throughout the film. To emphasize the discontinuity of the two spaces, Osorio uses editing creating juxtaposition. First, we see Josefina seated in her apartment talking on the phone with Santiago. The camera never captures Santiago's side of the conversation, illustrating the lack of connection between him and Josefina and the control she has over him. Josefina speaks loudly and rapidly and her voice is punctuated by a rising tone. Much like the beginning scene in which she insisted that Santiago deliver Laura's cake, she sounds disapproving and annoyed. She introduces the topic of Santiago's constipation. Rather than demonstrating empathy regarding Santiago's health issue, she asks: "Who will have to put up with your complaining about constipation?" Thus, she insists that he share about his constipation with Laura. When he refuses, she requests to speak to Laura and tells her of Santiago's constipation. Here, we see the intensity of her intrusiveness. She can't keep a personal matter confidential. Santiago is oppressed and his actions and bodily functions are dictated and monitored by Josefina.

When Laura takes the phone, the camera now films her standing next to Santiago in a medium long shot as she talks to Josefina. This change in setting represents a transition in Santiago's life. Laura speaks softly and calmly and never sounds annoyed. Although the introduction of the theme of constipation embarrasses Santiago, it catalyzes a deeper intimacy between him and Laura. Here, the spectator witnesses the first time Santiago really challenges what Josefina says. Referring to the topic of constipation, he says: "She's exaggerating. Don’t listen to her." 
While Laura finishes the conversation with Josefina, Santiago has to use the bathroom. The blue shading of the bathroom and the low light punctuate the private, intimate space. There is no toilet paper in the bathroom. Unsure of what to do Santiago, looks around the bathroom for an alternative. He finds two books on Laura's toilet tank visible in a close-up. This is the second time that Laura's books capture his attention. The first book he encounters in this scene is entitled El Hombre, La Mujer, y La Noche or The Man, The Woman, and The Night. The implications of this title foreshadow the events to take place in the rest of the film, for he in the man, Laura is the woman, and the circumstances surrounding the assassination have placed them together on this night.

In the background, the spectator sees another book Hombre sin Presente or Man without a Present which is authored by Jaime Osorio, an allusion to director Jaime Osorio. The title of the book is out of focus, suggesting that Santiago is slowly becoming aware that his life with Josefina does not allow him to enjoy the present moment. Furthermore, Laura's book authored by Osorio suggests shared social and political inclinations, recalling an earlier moment in which Santiago noticed another of her books. Thus, Santiago shares ideas with Laura and not with Josefina, who belittles his political convictions. The spectator can only clearly see the title of the second book, The Man, The Woman, and The Night. The metaphors and cinematic presentation of both of these titles suggest that Santiago has become aware that he and Laura will have to spend the night in her apartment. However, he doesn't have complete clarity that he lacks a present.

The close shot of the books pulls back to a medium shot of Santiago exploring the contents of Laura's medicine cabinet. The scene is adorned with the feminine intimate apparel hanging in the shower. Although his need for toilet paper may have served as a pretext for opening the cabinet, it is clearly too narrow to contain the toilet paper. Is he looking for the castor oil that Josefina mandated on her call? As he nervously searches through Laura's intimate items in the cabinet, the spectator gets the sense that he searches for intimacy and authenticity. After he searches through her medicine cabinet, he opens a container filled with old pictures. Even though there is clearly no toilet paper in the container, he says "maybe over here." Then he looks through some of its contents including some pictures and reads a part of a letter that a former lover had written her.

Osorio uses mis-en-scène to draw parallels between the Santiago's political oppression and his interpersonal oppression. As Martínez (2008) suggests, "filmmakers have not totally abandoned making social commentary to reflect their nations' . . history." In his search for paper, Santiago finds a tiny card in his wallet featuring a red tie supporting the assassinated presidential candidate, of whom Josefina didn't approve. He also wears a red tie. Earlier in the film, Josefina disapprovingly inquired about his choice of tie color. He denied its redness, instead calling it "wine." The scene ends with images of water. Laura fills containers in anticipation of a loss of the water supply. She forgets that she has left the water running in the sink. When Santiago returns to the kitchen area, he tries to dry it up. Laura playfully laughs at him. He requests newspaper to put on the floor. The use of water and the newspaper suggests that Laura and Santiago will purify themselves of the chaotic news of Gaitán's assassination. Water is a life-saving force that will allow Santiago to flow and express himself, thereby liberating him from the two layers of his oppression.

As the film concludes, Josefina visits Laura to say that Santiago has died. At that moment, the spectator sees a close-up of his cigarettes, the brand of which are "dandy." A dandy is a male who is very concerned with his appearance and clothes. This image creates a tension for the spectator. Josefina's concern for manners and appearances pushed Santiago to spend the night with Laura. At the end of the film, his dandiness has been left behind in favor of a self-expressive existence with Laura. The spectator only sees Santiago leaving Laura's apartment, thus giving the impression that he is still alive and has gained a richer life by making Josefina think he died in the violence. 
While Confesión a Laura touches on the violence of El Bogotazo beginning in 1948, Luis Alberto Restrepo's La Primera Noche portrays a narrative of disturbed "communitarian life" caused by "the deterioration of traditional, social, and democratic civil relationships," while, at the same time, disclosing images of survival "that are ethically affirmative in paradoxical ... shocking ways" (Herlinghaus, 2008, p. 4). Through the use of flash-backs and mis-en-scène elements, Restrepo illustrates the triangular nature of the more recent violence in Colombia. Restrepo draws parallels between the violence and the suffering of the characters, which is fragmented in time and space. The spectator witnesses a narrative of Colombian rural displacement from the intimate perspectives of Paulina and Toño and sees a triangle of structural violence between the military, the paramilitaries, and the guerillas through the lens of a love triangle. Toño and Paulina's relationship shows the spectator that the structural violence generates additional violence in the lives of peaceful people as they try to survive insurmountable obstacles.

A love triangle involving Paulina, Toño, and Toño's brother, Wilson, points to the damage that the armed conflict causes for the residents of the countryside. The two brothers fall in love with Paulina and she becomes pregnant by Wilson, without Toño ever resolving his feelings for her. Restrepo uses flashbacks to recount the story of Paulina and Toño, punctuated by the presence of military, guerillas, and paramilitaries that eventually force the dyad to escape the countryside for the capital of Bogotá. Toño is now a deserter of the armed forces and Paulina is an abandoned woman with two children. Wilson is a part of the guerilla movement and has no contact with her.

The film begins with Toño and Paulina desperately fleeing from the village to a friend's home. At this point, the spectator is not aware of the relationship between Toño and Paulina and it seems like Toño may be the father of the two children that Pauline carries along with her. This ambiguity may not be coincidental as the boundaries of traditional and social relationships are challenged by the violence. Toño is ridden with guilt as he cries and pounds on the wall: "It's all my fault. It's all my fault." Toño wears camouflage attire and the spectator gets the sense that he belongs to some military organization. However, at this point, it is not clear to which group he belongs. The grief-stricken couple is thrust into an even more desperate situation. Although the spectator does not know the details of the massacre, Toño recounts through his tears that his mother and other loved ones have been murdered. However, he has no time to process this pain. He must focus on his survival and that of Paulina. He asks his friend to lend him clothes and strips out of his camouflage attire. They will flee the countryside and he will desert his military organization.

The importance of Toño's desertion cannot be taken lightly. Toño asks his friend to burn his camouflage attire in case "they" come looking for him. Toño instructs his friend to allow Paulina to stay at his home for a few days and then take her to her family in a town called Esperanza. Paulina refuses. She says, "There is no Esperanza." Although the English translation misses the potentially metaphorical significance of what she says, the Spanish word esperanza translates to "hope." Paulina says, "There is no hope. There is no reason for me to go back." She is not headed in the direction of hope. Hope was destroyed in the same way that Toño's village and family were destroyed. Paulina's hope for a new life in Bogotá will soon be shattered, too. As she heads out into the dark night followed by Toño, she expresses her solitude and insists that she will stay alone.

Indeed there is no hope for Toño now that he has left the army. The decision that both he and his brother had made to join one of the factions in the triangle - the military, the paramilitary, or the guerillas - represents perceived social empowerment and mobility, rather than ideological conviction. In one of the flashback scenes, Toño recalls a lunch that he had with his family. His brother Wilson tells their uncle that he will join him in the mountains as a guerilla. The uncle then invites Toño to the join him in the mountains. Toño replies, "Uncle, the 
truth is I want to go to school. As soon as I can, I'm going to the city." Toño sees the military as a segue to attending the university. Although his uncle and brother tease him, they seem to see no ideological conflict between their seemingly oppositional work as guerillas and Toño's ambitions.

The scene flashes back to Toño walking around the city trying to get Paulina a hot drink. The consequences of deserting the military are readily apparent. The police aggressively search him for his identification and steal the little change that he has in his pockets. The police, who represent the society, value him even less now. Joining the military has had negative consequences. The spectator becomes aware that Toño cannot attend school since he defected from the military-the same military that permitted the slaughter of his mother and the burning of his village. The police treat him as if he is a delinquent.

The triangle of violence paralleled by the love triangle places the women in the film as the heads of the families due to the absence of the men. Elvia, the mother of Toño and Wilson, obstinately refuses to leave her land despite warnings from her guerilla brother and the military. Paulina decides to flee to the city with her two children and makes a decision to survive via prostitution. Prostitution was clearly the fate of her friend, whose contact information she carries along with her. However, the role of head of the family has been thrust upon these women and is taken on as a form of survival, rather than as social transformation. The women must negotiate their survival in the presence of structural violence, rather than resistance to patriarchal norms. These women live in an environment lacking stability, shelter, and safety. All of the characters live their lives in a structure with unclear boundaries and no clear power relationships. As Herlinghaus suggests, "juridical" power does not necessarily imbue their situations (p. 4-5). In La Primera Noche, both the males and the females attempt to negotiate their survival by non-ideological participation in the society.

Restrepo places the two protagonists, Paulina and Toño, on a Bogotá street corner where each individual has too much pain to even begin to understand the pain of the other. A travel agency is located on this street corner and much of the Bogotá scene takes place in front of a poster that reads: "Disfrute el Fin del Mundo." This expression can be transliterated from Spanish to mean "Enjoy the End of the World" or "Voyage to the End of the World." In order to step out of the parallel triangles, the protagonists may need to take this voyage. However, the apocalyptic allusion leads into the ending. Paulina prostitutes herself to a homeless man for about 25 U.S. dollars. Toño does not have the strength to express the love that he has for her. This love could have allied the pair so that they could confront the cruelties of the city, but the violent trauma they've suffered is too deep. They cannot go to this place.

As La Primera Noche suggests, the main challenges facing Colombia may be "defined ... in poverty, inequality, and weak civilian government institutions" (Center for International Policy, Latin America Working Group Education Fund, \& Washington Office on Latin America, p. 24). Likewise, the relationships that the protagonist of Antonio Dorado's El Rey has with his community and associates suggest what Chomsky, in his writings "On Colombia" calls the "dual structure" (p. 6). In the dual structure, "crimes ... are institutionalized" and there exists a "prosperous minority and an impoverished, excluded majority, with great differences in wealth, income, and access to political participation" (p. 6). El Rey tells the story of the double standards surrounding the evolution of the drug trade in the Colombian city of Cali through the narrative of Pedro Rey. Using edits and misen-scène elements, Dorado shows the double nature of the protagonist's growth into the pioneer of Colombia's international drug trade.

The first scene foreshadows the milieu of double standards that will be seen in the rest of the film. Against a dark backdrop the spectator sees a still shot of a pool table and billiards, while an invisible narrator calls El Rey "the man who would change the fate of his city." At the conclusion of the narrated part, the scene flashes through more than ten edits of fast moving billiards, a fast moving car, shoot outs with firearms, and a close-up of 
typewriter keys moving quickly. Soon, the scene changes to a Spanish colonial-style plaza replete with cobble stones and a colonial-style church. The narrator tells the spectator that the U.S. Alliance for Progress and the Peace Corps came to Colombia, though some Colombians hoped for a communist revolution. The American organizations alleged that they "came to try to save ... [Colombia] from poverty, hoping to stamp out the contagious disease of communism." Here, the narrator implies that the U.S. government developed a presence in Colombia under the guise of combating one supposed evil, only to breed another evil-the drug trade.

The spectator is now introduced to El Rey, a seemingly personable man who professes to see no conflict between his goals and the presence of North Americans. As the recently fired Camarada recounts the loss of his job due to union membership, El Rey approaches the "gringo bastards" walking through the plaza to promote his nightclub. The male, Harry Desmond, seems to have a very shallow understanding of the culture and the people, despite claiming to be an anthropologist. He cannot even understand El Rey's simple name, and seems to be delighted when El Rey calls himself "Peter King," a literal translation of the name "Pedro Rey."

Each transaction involving El Rey leaves its impression on the morals and values of the community. In the next edit, El Rey opens the shudders at his nightclub in a dingy, basement-like location. El Rey defines his double existence as both an enforcer of the new criminal and civil code and its biggest violator. As Blanca walks up the street carrying two bags, a petty thief runs by and swipes one from her. As she screams, El Rey trips the thief and beats him up. What El Rey tells the thief suggests the hypocrisy of the dual structure: "Didn't I tell you to respect your block?" For a moment, it seems like the thief may defeat El Rey when he pulls a knife on him. However, El Rey doesn't even wince and kicks the knife out of his hand. This double movement of enforcing respect for the block while simultaneously violating this respect will play out throughout the movie as El Rey builds his empire.

El Rey reinforces his good cop image when he invites the frightened Blanca into his dark, dank establishment. He encourages her not to be scared by saying: "It's okay. Not all of us 'caleños' are like that." (Note: A caleño is the Spanish word for someone from Cali, Colombia.) However, she should be frightened. He will introduce her to cocaine and after she becomes his lover and later his wife, he will beat her and cheat on her. He always carries a firearm and will show no loyalty to anyone, including to her.

When Blanca expresses her worry that the thief may return, El Rey further inculcates a Robin Hood aura. "If he's so smart, let him steal from those who can afford it." He goes on to say "I'm getting sick and tired of those thieves." Blanca has asked him for a job and while the pair flirts with each other, Doctora Arizmendi calls him. The spectator soon sees El Rey in the office of the father of Doctora Arizmendi. He finds out he will have to pay his rent to her, instead of her father. This situation sets up a tension as Doctora Arizmendi will later be his lover as well as a member of the government, financed by El Rey thereby empowering him to build his crime empire. He functions above the law because he literally has bought his own political representative.

The scene then edits back to El Rey's bar, where he seduces Blanca for the first time. As he flatters her with compliments, one can hear music in the street. El Rey tells Blanca that he has invited the musicians to serenade her, a comment that helped him to accomplish his sexual conquest. The scene edits to the street and the spectator hears the narrator's voice explaining that the musical group is a front for a band of thieves who steal from everyone. The musicians play while the bandits load the truck with furniture and anything else they can get their hands on. The irony of the double structure becomes apparent. El Rey does not prevent the thieves from engaging in their deeds and even uses their music to his sexual advantage. He lies about the crime associated with the music and on that lie he begins his relationship with Blanca. Despite his mantra of "respect the block," he is willing to buy the stolen booty from El Pollo, even after he chastises him with this same mantra. 
Throughout the film, El Rey converts himself into a member of the prosperous minority by exhibiting principles of corruption through which he buys relationships with the police, government, and others necessary for him to increase his wealth. He forms functional relationships with associates, advisors, and merchants such as Camarada, Doctora Arizmendi, Harry, El Pollo, and petty thieves and drug dealers to grow his enterprise from the distribution of drugs on the streets of Colombia to the exportation of cocaine to the United States and Europe. El Rey has abandoned his more impoverished roots and installs himself in the community as a type of Robin Hood figure. However, he cultivates his power through the constant threat of violence towards his associates and if he senses any betrayal, even amongst the many he has betrayed, he will not hesitate to take a life. The contradiction of the dual structure ultimately results in his demise, as his North American Peace Corps-affiliated international drug dealing associate shoots him. Only El Rey's hypocrisy can be superseded by a murder committed by someone claiming to be a representative of the Peace Corps.

All three Colombian films Confesión a Laura (Jaime Osorio, 1991), La Primera Noche (Luis Alberto Restrepo, 2003) and El Rey (José Antonio Dorado, 2004) challenge their viewers to deal with the violence, personal and political oppression, and double standards experienced by and sometimes facilitated by the leading characters in the Colombian socio-political landscape. With the exception of El Rey, the films are unlike their Hollywood analogues due to the characters' complexities and the directors' avoidance of good/bad dualisms. However, all three films highlight the moral struggles of the protagonists in an unstable social and political environment. The three directors make use of cinematography techniques, mis-en-scène, dialogue and sound, as well as editing to confront the spectator with these complexities of life in Colombia. In two of the films, $L a$ Primera Noche and El Rey, the spectator ultimately witnesses the destruction of the protagonists. In the case of $L a$ Primera Noche, Paulina succumbs to street life and quickly engages in prostitution while Toño's love for her never is requited. Pedro Rey's demise comes with his death at the hands of a U.S. associate. Despite his death, however, the spectator realizes that the environment replete with double standards, in which he operated, has already been created and sustained sufficiently to continue after his death. Dorado implicates U.S. government involvement in Colombian society as at least partially responsible for Colombian socio-political maladies. In contrast, Osario liberates his protagonist Santiago from the oppression he has suffered with his wife and through this escape Santiago will be able to express his political views to Laura, despite the politically repressive society in which he lives.

\section{References}

Center for International Policy, Latin America Working Group Education Fund, and Washington Office on Latin America. (2007). Below the radar: U.S. military programs with Latin America, 1997-2007. Retrieved from http://www.lawg.org/storage/documents/below\%20the\%20radar.pdf

Chomsky, N. (2004). On Colombia. In D. Stokes, America's other war: terrorizing Colombia (pp. viii-xviii). New York, NY: Zed Books.

Dorado, J. (2004) El Rey. [Motion picture.] Colombia: Eurocinè. Herlinghaus, H. (2008). Violence without guilt: ethical narratives from the global South. New York, NY: Palgrave Macmillan.

Martínez, G. (2008). Jump cut: A review of contemporary media. Retrieved from www.ejumpcut.org/archive/jc50.2008/LAfilmLaw/index.html. 
Osorio, J. (1991). Confesión a Laura. [Motion picture]. Colombia/ Cuba: Instituto Cubano del Arte e Industrias Cinematográficos.

Restrepo, L. (2003). Primera Noche. [Motion picture]. Colombia: Congo Films.

Melissa R. Meade is a doctoral student in the Mass Media and Communication program at Temple University. She was a Senior Lecturer of Liberal Arts at the University of the Arts. She earned her Master of Science in Intercultural Communication and Advanced Graduate Certificate in Women, Gender and Sexuality Studies from the University of Pennsylvania. Melissa earned a graduate degree in Intercultural Studies from the University of the Basque Country and was a Visiting Professor of International Programs at Instituto Tecnológico y de Estudios Superiores de Monterrey (ITESM), Querétaro Campus, Mexico. Her research interests include: Political communication; identity and inequality; Latino immigrants in the U.S.; migration and citizenship; language, gender, race, class, and disability; discourse analysis; and visual communication. 